\title{
REFORMA POLICIAL Y PROFESIONALIZACIÓN EN SEGURIDAD AEROPORTUARIA (2005-2015)
}

\author{
Gabriel Costantino ( ${ }^{(\cdot)}$ \\ Mariana Gutiérrez $(\cdot \bullet)$ \\ ISSA-PSA / UNSAM
}

\section{RESUMEN}

La investigación examina el proceso de implementación de la oferta formadora y capacitadora de la Policía de Seguridad Aeroportuaria en Argentina, y sus consecuencias en la profesionalización policial. La metodología de investigación combina el análisis documental, de recursos burocráticos, y entrevistas y encuestas a los actores involucrados sobre los cursos de formación y capacitación de la Policía de Seguridad Aeroportuaria. Los resultados muestran que los reformadores de la ex Policía Aeronáutica Nacional han tenido un alcance limitado en el cumplimiento de sus objetivos en materia de formación, capacitación y profesionalización policial. En las conclusiones se discuten las implicancias de los resultados de esta investigación para el debate más amplio sobre formación y profesionalización policial en este país.

\section{PALABRAS CLAVE:}

frormación policial, profesionalización policial, reformas policiales, Policía de Seguridad Aeroportuaria.

\section{ABSTRACT}

This article examines the execution process of basic and specialty training programs in Policía de Seguridad Aeroportuaria [Airport Security Police] in Argentina, and its impact on police professionalism. The research methodology combines documentary and bureaucratic resources as well as interview and survey analysis on training courses of the Policía de Seguridad Aeroportuaria. The findings show that effective implementation of the objectives held by reformers of the former Policía Aeronáutica Nacional [National Aeronautic Police] in the matter of police training and professionalization have been limited in scope. Finally, we discuss the implications of the results for the wider debate on police training and professionalization in this country.

\section{KEY WORDS :}

police training, police education, police reform, Policía de Seguridad Aeroportuaria.

\footnotetext{
(•) E-mail: gcostant76@gmail.com

$(\bullet)$ E-mail: mariana.gutie@gmail.com
}

RECEPCIŌN: 09/11/16

ACEPTACIÓN FINAL: 12/04/17 